\title{
CAUSATIVE CONSTRUCTIONS IN JAPANESE AND SLOVENE
}

\section{Introduction}

Whereas Japanese has a productive causative morpheme - $(s)$ ase- that is added to a non-causative verb to derive a causative verb, Slovene has no such single morpheme that may be considered to directly correspond with the Japanese morpheme. This article considers causative constructions first from a typological perspective, and then in present-day Japanese and Slovene by examining a small corpus of literary texts. The use of the Japanese causative morpheme is analyzed according to the characteristic of agency. For the most typical causative situation (with agentive causer and causee), corresponding Slovene constructions are analyzed.

\section{Causative situation, causative constructions and causative semantics}

A causative situation is such that an event is brought about by some outside entity. For example, Comrie (1985) states:

If we take a sentence containing a non-causative verb (or other predicate) to be describing a certain situation [s], then a sentence containing the corresponding causative verb will describe a situation [s/cause/] where some entity (person, thing, abstract force) either brings about situation [s] or, at the very least, fails to prevent [s]. Syntactically, one of the main differences between non-causative and causative constructions will be the increased valency (or potential valency) of the latter, since in addition to the participants in [s] there will also be the actant that brings about [s]. (Comrie 1985: 330-331)

Comrie (1985) continues with English and Turkish examples to illustrate analytic (or syntactic), morphological (or synthetic), and lexical causative constructions.

(1) Sam slid off the roof.

(2) Mary brought it about that Sam slid off the roof.

(3) Mary caused Sam to slide off the roof.

(4) Mary made Sam slide off the roof.

If one takes what is expressed in sentence (1) as the certain situation [s], then corresponding analytic causatives in English would be sentences (2), (3), and (4), where the idea of causation is expressed by the verbs bring about, cause, or make (Comrie 1985: 331). A morphological causative means that the predicate of [s] undergoes some derivational process in order to express causativity, as in (6) below from Turkish, where (5) represents [s]; the derivational process is the addition of the suffix -dür: (Comrie 1985: 331) 
(5) Hasan öl-dü.

Hasan die-PAST

'Hasan died.'

(6) Ali Hasan-i öl-dür-dü.

Ali Hasan-DO die-CAUSE-PAST

'Ali caused Hasan to die. / Ali killed Hasan.'

The alternative English gloss to sentence (6), according to Comrie, exemplifies lexical causatives. The verb used in describing [s] in English here is die, but to indicate that Ali brings about [s] one may use a completely different lexical item, kill, which has no morphological resemblance to die; kill is thus the lexical causative of die (Comrie 1985: 323, 331).

According to Comrie, formation of analytic causatives is completely productive. Formation of lexical causatives is by definition non-productive because there is no regular pattern to be extended to new items. The degree of productivity of morphological causatives varies from language to language, from languages such as English with only a few fossilized pairs (lie/lay, sit/seat) to languages such as Turkish, in which virtually any verb (including a causative verb) can form a causative (Comrie 1985: 332).

As for the semantics of causatives, the degree of closeness between the cause (i.e., the causer's actions) and the effect (resultant situation) comes into question (Comrie 1985: 332-333). Although an absolute distinction between mediated and immediate causation is difficult to draw, one often finds that, if a language has both analytic and morphological or lexical constructions, the former imply less direct causation than the latter, as in the Russian examples below (Comrie 1985: 333):

(7) Anton slomal paločku.

Anton(NOM) break(TRANS)-PAST stick(ACC)

'Anton broke the stick.'

(8) Anton sdelal tak, čtoby paločka slomala-s'.

Anton(NOM) do-PAST so that stick(NOM) break(INT)-PAST

'Anton brought it about that the stick broke.' (For example, Anton pushed against the lever that released the weight that fell on the stick, Comrie 1985: 333)

A similar distinction is sometimes found between non-productive (lexicalized or virtually lexicalized) and productive morphological causatives, the former implying greater closeness between cause and effect; for example, in Nivkh, the productive morphological causative in - $g u$ (Comrie 1985: 333):

(9) Lep ce-d'.

bread dry(INT)-PAST

'The bread dried.'

(10) If lep seu-d'.

he bread dry(TRANS)-PAST

'He dried the bread.' 
(11) If lep ce-gu-d'.

he bread dry(INT)-CAUSE-PAST

'He caused the bread to get dry (e.g., by forgetting to cover it).'

Another aspect of the relation between causer and effect is the difference between causative proper and permissive meaning. For example (Comrie 1985: 333):

(12) I made John climb the tree.

(13) I let John climb the tree.

Analytic causative constructions generally have distinct predicates for causation proper and permission; for example, English cause, make verses allow, let. Lexical causatives typically express causation proper, but morphological causatives often cover the range of both causation proper and permission. Consider the following example in Nivkh (Comrie 1985: 334):

(14) Ni atik-ax ph-emek vi-gu-d'.

I younger brother-CAUSEE own-mother go-CAUSE-PAST

'I made/let my younger brother follow my mother.'

\section{Causative expressions in Japanese}

The syntactic, semantic, and morphological characteristics of the Japanese causative 'shieki' are defined by Teramura (1982) as follows:

In the typical sentence structure: W ga X wo (Y ni) / ni V-(s)ase-ru, W NOM X ACC (Y DAT) /DAT V-CAUSE-PRESENT

$\mathrm{W}$ brings about, or cannot prevent, a situation in which $\mathrm{X}$ does something (to Y); or W feels responsible for the situation brought about (Teramura 1982: 290).

The distinctive Japanese morpheme -(s)ase-, called shieki-ji ('causative suffix'), is a productive means to derive causative verbs from non-causative verbs. For example:

(15) Tarô ga gakkô e itta.

Tarô NOM school DIR go-PAST

'Tarô went to school.'

(16) Haha ga Tarô wo gakkô e ikaseta.

mother NOM Tarô ACC school DIR go-CAUSE-PAST

'Mother made Tarô go to school.'

(17) Haha ga Tarô ni gakkô e ikaseta.

mother NOM Tarô DAT school DIR go-CAUSE-PAST

'Mother let Tarô go to school.'

Taking what is expressed in sentence (15) as the certain situation [s], the corresponding morphological causative to express a situation [s/cause/] in Japanese is sentence (16). The lexical verb iku 'to go' combines with the derivational morpheme $-(s)$ ase- to form the causative verb ikaseru 'to make (someone) go'. Sentence (17) is another variation of the causative expression: whereas sentence (16) expresses immediate causation with the case particle wo, sentence (17) conveys permissive meaning with the case particle $n i$. The semantics of sentences (16) and (17) may be compared somewhat parallel to the example sentences (12) and (13) in the previous section, below as (18a) and (18b): 
(18a) I made John climb the tree.

(18b) I let John climb the tree.

If the certain situation [s] is a transitive action with a direct object as in sentence (19) below, the case particle wo is already taken, so the corresponding causative sentence expressing [s/cause/] has no variation. Sentence (20) below may convey the causative proper as well as permissive meaning.

(19) Tarô ga ringo wo tabeta.

Tarô NOM apple ACC eat-PAST

'Tarô ate an apple.'

(20) Haha ga Tarô ni ringo wo tabesaseta.

mother NOM Tarô DAT apple ACC eat-CAUSE-PAST

'Mother made Tarô eat an apple. (= Mother fed Tarô with an apple.)/

Mother let Taro eat an apple.'

Teramura (1982) states that the causer of the Japanese causative construction is usually an animate being. If not, the expression is felt as a personification (1982: 293). Most typically, the Japanese causative is used when both the causer and the causee are human beings, and usually when the causer is superior to the causee (Teramura 1982: $301)$. However, there are cases when the morpheme - $(s)$ ase- appears even when the causee is inanimate. This happens when there is no transitive counterpart of a certain intransitive verb: in this case, the derived causative verb with the causative morpheme takes over the role of the transitive verb that happens to be absent in the Japanese lexicon (Teramura 1982: 293-296). For example, although there is a pair of intransitive and transitive verbs with the common root $a k$-, aku 'to open [intr.]' and akeru 'to open [trans.]', there is no transitive counterpart to the intransitive verbs hikaru 'to shine, glisten' and sumu 'to be settled, finished'. Observe:

(21a) Mado ga aku. window NOM open(INT)

'The window opens.'

(22a) Garasu ga hikaru. glass NOM shine(INT)

'The glass shines.'

(23a) Kanjô ga sumu. account NOM settle(INT)

'The account is settled.' (21b) Mado wo akeru. window ACC open(TRANS)

'(I) open the window.'

(22b) Garasu wo hikaraseru. glass ACC shine(INT)-CAUS

'(I) make the glass shine.'

(23b) Kanjô wo sumaseru. account ACC settle(INT)-CAUS

'(I) settle the account.'

For expressions that may stand parallel to example (21b) with the transitive verb akeru, the derivational causative morpheme -(s)ase- appears for the transitive expressions $(22 b)$ and $(23 b)$.

The morpheme - $(s)$ ase-, which has just been seen above, is an example of grammatical means to create the voice opposition of non-causative vs. causative. What is called the 'semi-lexical' opposition of voice in Japanese (Noda 1991) are morpholo gical forms such as -as-, $-s-$, -ar-, and - $r$-, which appear only in certain verb pairs with a common verbal root. In the example pairs below, the morphological form $-s-$, which seems historically related to the derivational causative $-(s) a s e-$, is found in the transitive counterpart of each pair: 
Intransitive

kowareru 'to break(INT)'

okiru 'to get up, rise'
Transitive

kowasu 'to break(TRANS)'

okosu 'to wake, raise'

The third type of opposition, so-called 'lexical' by Noda (1991), is realized by verbs of no common morphology. A typical example is the verb pair shinu 'to die' vs. korosu 'to kill'.

(24) Tarô ga shinda.

Tarô NOM die-PAST

'Tarô died.'

(25) Hanako ga Tarô wo shinaseta.

Hanako NOM Tarô ACC die-CAUS-PAST

'Hanako let/made Tarô die.'

(26) Hanako ga Tarô wo koroshita.

Hanako NOM Tarô ACC kill-PAST

'Hanako killed Tarô.'

Taking the expression in sentence (24) as the certain situation [s], the corresponding morphological causative to express a situation [s/cause/] is (25). Here the derived causative verb conveys mediated causation, something like 'Hanako let Tarô die by not caring for him enough, etc.' The transitive counterpart of the lexical opposition, the verb korosu 'to kill' in sentence (26), on the other hand, expresses direct causation; i.e., 'Hanako killed Tarô by stabbing with a knife, etc.', though of course the degree of closeness between the cause and the effect depends on the individual context in which each expression appears.

\section{Causative expressions in Slovene}

Toporišič's encyclopedia of the Slovene language (1992) carries an entry »causative verb « (vzročniški glagol) and it is explained that causative verbs express the achievement of someone's purpose that some event comes true. Examples are (Toporišič 1992: 362):

pojiti/napajati $=$ povzročiti/doseči, da kdo/kaj pije

'to supply (with water, fuel etc.) = to cause/achieve that s.o./s.th. drinks'

točiti $=$ povzročiti/doseči, da kaj teče

'to pour $=$ to cause/achieve that s.th. flows'

uspavati $=$ povzročiti/doseči,$d a k d o$ spi

'to lull = to cause/achieve that s.o. sleeps'

In Toporišič's grammar under »morphological means of expressing transitivity « (2000: 353 -354), the following three derivational means are listed:

i) Pairs of verbs with vowel gradation:

Intransitive $\underline{\text { Transitive }}$

rumeneti rumeniti

oživeti oživiti

'to turn yellow' vs. 'to make yellow'

'to become animated' vs. 'to revive'

ii) Preposition as a free verbal morpheme:

hoditi 'to walk' hoditi za 'to try to obtain s.o.'s affection'

iii) Taking the morpheme se from the intransitive verb: 
Steklenica se je razbila.

bottle(NOM) break(INT)-PAST

'The bottle broke.'

Razbil je steklenico.

break(TRANS)-PAST bottle(ACC)

'He broke the bottle.'

The first means (i) is very similar to the »causative verb « above. Although the systematic vowel alternation $-e-/-i$ - is not seen in the former examples of the causative verb, the shared etymology is observed in each pair. If the pairs are examined semantically, the intransitive/transitive opposition is seen in the same manner with the following verb pairs: piti/pojiti, teči/točiti, and spati/uspavati. It is in fact the causativization process of gaining a new argument, an agent, whose purpose is to realize the event expessed by the intransitive counterpart (Shigemori Bučar 2003: 100). The second (ii) is mentioned in Dular (1982: 147) as one of the word formation processes to gain a place for a new argument. The example cited in Toporišič (hoditi vs. hoditi za) is not a simple semantic pair of intransitive and transitive verbs by way of derivation, but the transitive counterpart has an additional semantic value, as pointed out by Dular (1982: 147). Another such example is found in the verb pair poslati 'to send' vs. poslati po 'to send for'. The preposition $p o$ in this case combined with the lexical verb poslati derives a new verb with a causative meaning (Shigemori Bučar 2003: 242):

(27) Janeza smo poslali po zdravnika.

Janez(ACC) send(1.p.pl.)-PAST for doctor(ACC)

'We sent Janez to get the doctor./We sent Janez for the doctor.'

The third means mentioned by Toporišič (iii) is one of the main means of intransitive/transitive opposition in Slovene.

These are all derivational processes of verbs between 1-place (intransitive) and 2place (transitive) variations of the same semantic base of events, but none of them are productive in modern Slovene. The vowel alternation $-e-/-i$ - is observed in a few fossilized pairs of verbs and, together with intransitive/transitive opposition of the type pojiti/napajati, most of these pairs have become semantically quite distant and are actually used in quite different contexts in modern Slovene (Shigemori Bučar 2003: 214). These and the lexical oppositions of the type razbiti se/razbiti may be called "semi-lexical" oppositions of voice in Slovene. "Lexical" opposition would be, for example, ostati "to stay'/pustiti 'to leave', or pasti 'to fall'/spustiti 'to let fall, drop', etc.

Orešnik (1992) expected that morphological causative verbs would display 3-role semantic valency. However, his analysis of all verbs under the letter $j$ shows that most of the verbs of 3-role semantic valency are verbs of saying. Instead, many causative verbs are present among the verbs of 2-role semantic valency (Orešnik 1992: 184-185). An example of a rare 3-place causative verb in Slovene is učiti 'to teach'. Sentence (29) is an analytical interpretation of sentence (28), also by Orešnik (1982: 185): 
(28) Janez poučuje Micko matematiko.

Janez(NOM) teach-PRES Micka(ACC) mathematics(ACC)

'Janez teaches mathematics to Micka.'

=(29) Janez dela neposredno, da se Micka uči matematiko.

Janez(NOM) do-PRES directly that Micka(NOM) learn-PRES mathematics(ACC)

'Janez does it directly that Micka learns mathematics.'

\section{Hypothesis for corpus analysis}

Both Japanese and Slovene have lexical and semi-lexical means of causative expressions, but they are limited to certain verbs and are not productive today. The productive derivational morpheme for the causative, on the other hand, is found only in Japanese.

Based on the survey of Slovene grammar (in the previous section), one may expect the causative expressions in Slovene to be found in one of the following constructions:

A. With a lexical or semi-lexical transitive (causative), 2-place, or 3-place verb

B. Analytical expression:

B-1. With 2 verbs of which the latter is in a subordinate clause

e.g., (30) Janez mu je dovolil, da vstopi.

Janez(NOM) he(DAT) permit(PAST) that enter(3.p.sg.PRES)

'Janez permitted him to enter.'

(31) Janez mu je rekel, naj vstopi.

Janez(NOM) he(DAT) say(PAST) should enter(3.p.sg.PRES)

'Janez told him that he should enter.'

B-2. With 2 verbs, of which the latter is in the infinitive

e.g., (32) Janez mu je dal piti.

Janez(NOM) he(DAT) give(3.p.sg.PAST) to drink

'Janez gave him to drink.'

B-3. With a verb and a verbal noun

e.g., (33) Janez mu je omogočil vstop.

Janez(NOM) he(DAT) enable(3.p.sg.PAST) entrance(ACC)

'Janez enabled him entrance./Janez made it possible for him to enter.'

C. With a phrasal verb of the type hoditi za 'to try to obtain s.o.'s affection', poslati po 'to send for'.

\section{Corpus analysis}

Literary texts in modern Japanese literature with direct translations in Slovene were chosen (altogether 197,730 Japanese characters, the list is found at the end of the article).

The analysis is in 2 parts: First, passages with the Japanese causative morpheme are searched throughout the chosen corpus and classified according to the agency of the causer and causee (Section 5.1). Second, for the most typical causative situation with the Japanese causative morpheme, corresponding Slovene expressions are analyzed according to their grammatical constructions (Section 5.2). 


\subsection{Japanese causative morpheme and agency}

There are 140 passages in which Japanese causative morphemes (the productive suffix $-(s)$ ase- and the semi-lexical morpheme $-s-)$ appear. These Japanese causative expressions were classified according to the distinction of agency. In accordance with the assertion by Teramura (1982: 293-301; see Section 2 above) and other Japanese grammarians, the productive causative morpheme is usually used and is also taught (e.g., in Japanese language teaching) within the context of both the causer and the causee being human beings; therefore, with agency or self-control of these two. Languages vary with respect to how often agency is lexicalized in verbs (e.g., Van Valin \& Wilkins 1996: 309-340), and it has been observed that Japanese verbs are more sensitive to the distinction of agency than are verbs in English (Shigemori Bučar 2003:15-16) and Slovene (Shigemori Bučar 2003: 199). However, one must also bear in mind that in some cases the derived causative verb in Japanese assumes the role of a transitive verb. (Teramura 1982: 293-296; see Section 2 above) Therefore, it may be expected that some passages with the derived causative may be of an inanimate/non-agentive causee.

Thus, the 140 cases of Japanese causative expressions are classified below (Table 1) according to the agency of the causer (the one that brings about the event [+agency] or a thing/force causing the event [-agency]), and the causee (the one that is acting in the event [+agency] or a thing with which some change is brought about in the event [-agency]).

Table 1: Agency of the causer and causee in Japanese literary texts (total 140 cases)

\begin{tabular}{|c|c|c|}
\hline Agency of causer & Agency of causee & Number of cases and $\%$ \\
\hline+ & + & $63(45 \%)$ \\
\hline+ & - & $51(36.5 \%)$ \\
\hline - & + & $10(7 \%)$ \\
\hline - & - & $16(11.5 \%)$ \\
\hline
\end{tabular}

It is interesting, when considering the definition of the Japanese causative and the sensitivity of Japanese to agency, that inanimate causers are still found in the Japanese corpus (18.5\% of the corpus). In Hasegawa (1992) it is argued that Japanese transitive verbs such as korosu 'to kill' and kowasu 'to break' take true agent arguments, not simply effectors. The Japanese situation is compared to the quite different situation in English. Van Valin \& Wilkins (1996: 309-340) cite the following example sentences:

(34) Larry killed the deer.

(35) Larry accidentally killed the deer.

(36) The explosion killed the deer.

and argue that sentence (34) is neutral and leaves room for our interpretation whether or not the subject Larry is an agent, that in sentence (35) the adverb accidentally is »agent-cancelling « and thus the subject Larry is interpreted as an effector but not the 
direct agent, and that in sentence (36) the subject is non-human and thus cannot be interpreted as the agent, but as the »force « that effected the killing. When the English sentence (36) is translated into Japanese, the following is observed (Shigemori Bučar 2003: 15):
(37) *Bakuhatsu ga shika wo koroshita. explosion NOM deer ACC kill-PAST
'The explosion killed the deer.'
(38) Bakuhatsu de shika ga shinda.
explosion INST deer NOM die-PAST
'The deer died due to the explosion.'

Whereas sentence (37) is difficult to accept, a translation possibility is found in sentence (38) in which the noun phrase 'explosion' is accompanied by the case particle de to express the cause of the event and 'deer' is in the nominative/agentive case as the central entity for which the event 'to die' occurs.

In the same manner, the passages found in the corpus with an inanimate/non-agentive causer (effector) may be formulated otherwise. Examples (39a) and (40a) are the original passages in the Japanese corpus 'Kagiri naku...', and (39b) and (40b) are my reformulations:

(39a) Toppû ga boku wo fukitobasu.

sudden wind NOM I ACC blow away(TRANS)

'A gust of wind blows me away.'

(39b) Toppû de boku ga fukitobu.

sudden wind INST I NOM be blown away(INT)

'I am blown away by a gust of wind.'

(40a) Pinku no keroido ga ue no hô made hifu wo hikitsurasete iru.

pink keloid scar NOM upwards skin ACC crinkle(INTR)-CAUS-STATE

'The pink keloid scar drew the skin upwards.'

(40b) Pinku no keroido de ue no hô made hifu ga hikitsutte iru.

pink keloid scar INST upwards skin NOM crinkle(INTR)-STATE

'Due to the pink keloid scar the skin is drawn upwards.'

The original passage (39a) contains an inanimate causer (topp $\hat{u}$ 'sudden wind'), a human causee (boku 'me'), and a transitive/causative verb with the morpheme -s- (fukitobasu 'to blow away'). In the reformulated sentence (39b), the animate participant of the event is in the nominative case with the particle ga (boku ga 'I'), the sudden wind is accompanied by the particle de to express the cause of the event, and the verb is intransitive (fukitobu 'to be blown away'). In (40a), which is also an original literary expression, the scar is the inanimate causer (keroido ga) and the skin is the causee, which is also inanimate (hifu wo). The verb in this passage is affixed with -ase-, which causitivizes the originally intransitive verb hikitsuru 'to crinkle'. My reformulation puts the skin in the center of the expression with the nominative case particle $g a$, and the inanimate causer keroido is accompanied by de as the cause of the event. 
These are all grammatically acceptable sentences in Japanese, but (39a) and (40a), especially (39a), are felt to be stylistically characteristic. It may be assumed that these cases of a non-animate/non-volitional causer are characteristic for the literary genre.

In many cases in these passages, the inanimate causer is a natural force (wind, the sound of rain, clouds, the sun, etc.), and in other cases traces of personification are seen; for example, another passage from 'Kagiri naku...':

(41) ...kage ga, kaibutsu ga ha wo mukidasu yôni boku-tachi wo odorokaseru. shadow NOM moster NOM teeth ACC bare as-if we ACC surprise-CAUSE-PRESENT 'The shadow frightens us, like a monster baring its teeth.'

It may be concluded that, in the modern literary genre, Japanese causative expressions with the productive causative morpheme - $(s)$ ase- or causative verbs with $-s$ - are mainly used with the causer being agentive (more than $80 \%$ in the present corpus), and most often when both the causer and the causee are agentive ( $45 \%$ in the corpus). There are also cases in which the causer is not an animate agent but simply an effector/cause of the event (a little less than $20 \%$ in the corpus).

\subsection{Slovene constructions for the causative situation with animate participants}

The 63 passages of the present corpus with both the causer and the causee being animate/agentive were further analysed in order to see which Slovene constructions correspond to the most typical Japanese causatives with the distinctive morphemes $-(s)$ ase- and $-s-$.

The results are listed below in the same order as the hypothesis in section 4 above. The classification of verbs as to whether they are 2-place or 3-place and the English translations of each expression are given according to the specific contexts of individual verbs. Some prepositional cases ( $z$ 'with' and $v$ 'in, into') are also counted as the third argument in clauses with a 3-place verb.

A. With a lexical or semi-lexical transitive (causative) verb: 34 cases

2-place (14 cases): dvigniti 'to lift, raise', narediti konec 'to put an end to', oplodi$t i$ 'to impregnate', peljati 'to drive, lead', pobrati 'to pick up', posaditi 'to plant', posesti 'to seat', presenetiti 'to surprise', priganjati 'to drive, spur, hurry', poslati nazaj 'to send back', udariti 'to beat, strike', ustaviti 'to stop', utrujati 'to tire', uvoziti 'to import';

3-place (20 cases): govoriti 'to speak', izpostaviti 'to expose', naliti $z$ 'to pour, fill with' (2), narediti 'to do', naznaniti 'to notify, inform', pokazati 'to show', poslati 'to send', povedati 'to tell' (3), predstaviti 'to present, introduce', reči 'to say, tell', vključiti $v$ 'to include in' (3), stisniti v 'to press, squeeze into', vpisati 'to register, enroll in', vtakniti $v$ 'to put into', zadeti 'to hit';

B. Analytical expression: 10 cases

B-1. With 2 verbs, of which the latter is in a subordinate clause: (5 cases) narediti, da počuti 'to make s.o. feel', pusititi, da opravi 'to let s.o. settle', pustiti, da počne 'to let s.o. do' (2), ukazati, da sede 'to order s.o. to sit'; 
B-2. With 2 verbs, of which the latter is in the infinitive: (4 cases)

dati piti 'to give to drink', dati stkati 'to have weave', dovoliti iti 'to permit to go', pustiti opazovati 'to let s.o. watch';

B-3. With a verb and a verbal noun (1 case):

ponuditi izkušnje 'to offer experience'

C. With a phrasal verb: none

34 out of 63 cases are expressions with a transitive verb (either 2-place or 3-place); altogether, $54 \%$ of 63 cases. Analytical expressions are found in 10 cases $(16 \%)$, much less than the cases with a transitive verb. The only disappointment is that no case of word formation (phrasal verb) of the type poslati po, hoditi za is found in the corpus. For the analytical expression, it must be noted that the distinctive predicates show the semantic subcategories of the original Japanese morpheme in one form. Whereas the semantic distinction between direct or mediated causation must be made according to the context in Japanese, the Slovene analytical expressions make this distinction by the choice of lexical verbs: ukazati 'to order' denotes direct or forceful causation, whereas pustiti 'to leave, let' and dovoliti 'to permit' denote mediated causation or more distance between the causer and the causee. One case is found in which the Slovene corresponding expression is a set phrase without any verb: po njegovih besedah 'in his words' for the original Japanese expression kare ni iwasereba 'if (I/we) let him say'.

The remaining passages are difficult to analyse in the given framework and need further discussion mainly due to the change in the viewpoint of narration. The following two tendencies are observed:

1. The causer-part of the expression is dropped in the Slovene corresponding passage, probably because the analytical expression is felt to be too complicated and stylistically awkward. The semantics of the causer are often included in a wider range of the narrative.

2. The original Japanese causative expression is a part of a more complicated pre dicate construction; i.e., causative-passive, causative-imperative, and links with giving and receiving verbs to denote benefit or favor. These constructions trigger a switchover in the viewpoint.

\section{Conclusion}

This paper is an attempt to search for common ground for contrastive analysis of the causative in Japanese and Slovene. Within the limits of a small corpus analysis in this paper (i.e., the most typical causative semantics with agentive causer and causee, and in the modern literary genre), the majority of passages with the Japanese causative morpheme found their equivalent in a transitive verb or in an analytical construction of two verbs in Slovene. Further research with a broader view of the semantics of the causative, using more corpora in various genres, may lead to more detailed accounts of this subject. 


\section{$\underline{\text { References }}$}

Comrie, Bernard (1985) Causative verb formation and other verb-deriving morphology, Language Typology and Syntactic Description Vol III: Grammatical categories and the lexicon, ed. Timothy Shopen, Cambridge Univ. Press, 309-348.

Dular, Janez (1982) Priglagolska vezava v slovenskem knjižnem jeziku (20. Stoletja) (Verbal goverment in literary Slovene (20 th century)), doctoral dissertation, Faculty of Arts, University of Ljubljana.

Hasegawa, Y. (1992) Syntax, Semantics and Pragmatics of te-linkage in Japanese, doctoral dissertation, University of California at Berkeley.

Noda, Hisashi (1991) 'Bunpô-teki-na Voisu to Goi-teki-na Voisu no Kankei' ('The Relationship between Grammatical Voice and Lexical Voice') Nihongo no Voisu to Tadôsei (Japanese Voice and Transitivity) Kurosio, Tokyo, $211-232$.

Orešnik, Janez (1992) Udeleženske vloge v slovenščini (Semantic Roles in Slovene), Classis II: Philologia et Litterae 37, SAZU, Ljubljana.

Shigemori Bučar, Chikako (2003) Voice in Contrast-Japanese and Slovene (Protistava glagolskega načina $v$ japonščini in slovenščini), doctoral dissertation, Faculty of Arts, University of Ljubljana.

Teramura, Hideo (1982) Nihon-go no sintakusu to imi I (Japanese Syntax and Semantics I), Kurosio, Tokyo.

Toporišič, Jože (1992) Enciklopedija slovenskega jezika (Encyclopedia of the Slovene Language), Cankarjeva založba, Ljubljana.

Toporišič, Jože (2000) Slovenska slovnica (Slovene Grammar), Založba obzorja, Maribor.

Van Valin, Robert D. Jr. \& David P. Wilkins (1996) The Case for 'Effector': Case Roles, Agents, and Agency Revisited, Grammatical Constructions: Their Form and Meaning, ed. Masayoshi Shibatani \& Sandra A. Thompson, Clarendon Press, Oxford, 289-322.

\section{Text corpus}

Chinmoku, MURAKAMI Haruki, 1998

Gotai Fumanzoku, Ibarin-bô, OTOTAKE Hirotada, 1998

Toshishun, AKUTAGAWA Ryûnosuke, 1920

Danmari-ichi, TSUSHIMA Yôko, 1983

Yasashii Sayoku no tame no Kiyûkyoku, SHIMADA Masahiko, 1983

Hôkago no Kî-nôto, Jay-Walk, YAMADA Eimi,1989

Kagiri-naku Tômei ni Chikai Burû, MURAKAMI Ryû, 1976
(18,400 characters)

(19,244 characters)

(10,741 characters)

(10,660 characters)

(31,434 characters)

(12,751 characters)

(94,500 characters)

Slovene translations of the first three texts are parts of undergraduate theses presented to the Dept. for Asian and African Studies, Faculty of Arts, University of Ljubljana; the following three are in Literatura, 16 (2004), Nos. 161 - 162, LUD Ljubljana; the last one was independently published as Skoraj prosojna modrina (2005), Cankarjeva založba, Ljubljana.

\section{Povzetek \\ VZROČNIŠKE ZGRADBE V JAPONŠČINI IN SLOVENŠČINI}

Medtem ko v japonščini obstaja produktivni vzročniški morfem -(s)ase-, ki se doda nevzročniškemu glagolu za izpeljavo vzročniškega, slovenščina ne razpolaga s čim podobnim, ki bi ustrezalo japonskemu morfemu.

Članek najprej tipološko povzema vzročniške zgradbe, nato na osnovi korpusa modernih literarnih besedil primerja vzročniške izraze $\mathrm{v}$ japonščini in slovenščini. Japonščina dobro označuje in ločuje živost aktantov, kar je delno potrdil tukaj obravnavani korpus. Več kot 80 \% vzročniških izrazov v japonskem korpusu (z vzročniškim morfemom -(s)ase- ali z vzročniškim glagolom $\mathrm{s}-s$-) spremlja človeški aktant (oz. povzročitelj) in pogosto sta oba člena, tj. povzročitelj kot tudi vzročno vplivano, živo bitje oz. človek. Našlo se je tudi nekaj primerov, pri katerih je aktant neživ (manj kot $20 \%$ ).

Večina japonskih izrazov $\mathrm{z}$ vzročniškim morfemom in s človeškim aktantom ima v slovenščini svojo ustreznico v zgradbah s prehodnim glagolom (54\%) ali z analitično zgradbo dveh glagolov (16 $\%)$. Primerov predložnomorfemskih glagolov po hipotetičnem pričakovanju v obravnavanem korpusu ni bilo. Nadaljnje delo na področju protistave japonskih in slovenskih vzročniških zgradb zahteva širši oz. obsežnejši pregled semantike vzročniškosti in predvsem z večjimi korpusi. 